\title{
ALTERNATIVES OF STORAGE OF CORN GRAINS FOR THE CONDITIONS OF THE BRAZILIAN CERRADO
}

\author{
ALTERNATIVAS DE ARMAZENAGEM DE GRÃOS DE MILHO PARA AS \\ CONDIÇÕES DO CERRADO BRASILEIRO
}

\section{Paulo Carteri CORADI ${ }^{1}$; Lucas Jandrey CAMILO² ; Fernando França da CUNHA $^{3}$; Taísa Lopes Lacerda PEREIRA ${ }^{2}$; Charline Zaratin ALVES ${ }^{1}$}

1. Professor, PhD., Universidade Federal de Mato Grosso do Sul - UFMS. Chapadão do Sul, MS, Brazil. paulocoradi@yahoo.com.br; 2. Undergraduated Student, Universidade Federal de Mato Grosso do Sul-UFMS, Chapadão do Sul, MS, Brazil. 3. Professor, PhD., Universidade Federal do Vale do Jequitinhonha, Unaí, MG, Brazil.

\begin{abstract}
The storage of grains under technical conditions in favorable environment ensures grain quality and regulates the supply of raw material for food production. For this reason, the objective of this study was to evaluate the different forms of storage (aerated silo, non-aerated silo, silo bags and airtight) of grains produced in the Brazilian cerrado, over time (zero, three and six months), for different physical qualities of maize (normal grains, whole grains and broken grains). The research was conducted at the Federal University of Mato Grosso do Sul (UFMS), Chapadão do Sul Campus (CPCS), Grain Postharvest Laboratory. To determine the physical-chemical quality and the physical properties of grains over six months, samples were taken from the stored lots. Analysis of variance and comparison of means by Tukey's test were conducted at $5 \%$ probability. The six-month storage time was the main factor contributing to the reduction of the quality of maize grains. Storage alternatives with aeration, non-aeration, bags and airtight environment did not influence the physical properties of maize grains. The broken maize grains showed the worst physical and chemical quality during storage time, while the batch of whole corn grains differ in quality during storage. It was concluded that airtight storage and storage in aerated silos were the conditions that best preserved the physical and chemical quality of maize grains over time.
\end{abstract}

KEYWORDS: Water content. Quality. Cerrado region. Ambient temperature. Zea mays L.

\section{INTRODUCTION}

Brazil is one of the leading maize producers worldwide, and the Midwest region is the main producer. Maize is the second most produced grain in Brazil, second only to soybeans (FAO, 2012). However, it is known that quantitative and qualitative losses of extremely variable magnitude occur both at the harvest and in all stages of postharvest system, transport, handling, drying, storage, processing, marketing and endpoints distribution to consumers. In Brazil, losses in the stages of postharvest of grains range between 25 and $30 \%$ of what is produced (FAO, 2012). After the corn grain harvest will be sold, or else stored for a period of time, seeking better market conditions for marketing.

During storage, it is essential to maintain the quality characteristics of maize grains and minimize quantitative and qualitative losses, as well as choose the best alternative for storage conditions, according to the region and the producer capitalization (ANTUNES et al., 2011).

Deterioration of the grains is a natural and inevitable process of physical disruption and loss of physiological capacity; however, it can be controled, and this is the essence of storage, which is one type of conservation strategy (ALENCAR et al., 2011). There are several ways to store corn; one of them is bulk storage in sacks and under controlled environmental conditions. Although the method chosen for grain storage is important, proper management of the operation should be performed strictly.

The main factors that affect grain quality during storage are temperature and water content, and they are related to the breathing of the product and the presence of microorganisms (CORADI et al., 2011). During (bulk) storage, grains are subject to changes in ambient temperature which, combined with water content of the grains, have a direct influence on the occurrence of insects and microorganisms (SANTOS et al., 2012). For better efficacy in bulk storage, it is recommended to install a thermometry and aeration system for control of grain mass temperature, thereby cooling the product and reducing the risks of growth and multiplication of microorganisms and insect pests.

Corn storage in sacks in conventional warehouses can be successfully used, provided that the storing structures meet the minimum requirements. Corn must be dry (13 to $13.5 \%$ moisture) and there must be good ventilation in the structure. The floor should be concreted and 
cemented and the perfect cover, with control and anti-rat protection, the piles of bags should be erected on wooden pallets and away from walls. In this type of storage, losses that occur due to insect attack can be minimized, because the methods for their control are effective.

The airtight environment for storage is an alternative to dry bulk storage of grains. In this system, there is no air exchange, and the grain, through its respiratory activity, consumes all the oxygen available. In the absence of oxygen, insects and fungi will not survive nor increase and therefore there will be no damage to the grains during the storage period (ANTONELLO et al., 2009). To reduce grain breathing, grains must be stored in cool, sealed locations, reducing oxygen concentration and accumulation of $\mathrm{CO}_{2}$, making the environment improper for the development of pest insects and microorganisms.

The reduction of light, temperature and humidity of both grains and environment reduce metabolism and infestation by microorganisms, increasing the longevity of grains (JIAN et al., 2012). However, the higher the temperature and the humidity in storage, the greater the physiological activity in grains and, consequently, the faster the deterioration (COSTA et al., 2013). Although airtight storage uses, sweetens conditions of low temperature and low grain moisture content, promote the quality, also considering the costs of proceedings, both in the choice of storage technique, as the management and control of the storage environment conditions. Thus, the aim of this study was to evaluate the different forms of storage (aerated silo, non-aerated silo, bags and airtight storage) of grains produced in the Brazilian cerrado, over time (zero, three and six months) for different physical qualities of corn (normal grains, whole grains and broken grains).

\section{MATERIAL AND METHODS}

The research was conducted at the Federal University of Mato Grosso do Sul (UFMS), Chapadão do Sul Campus (CPCS), Grain Postharvest Laboratory. The corn grains were stored for a period of six months from September 6, 2013 to March 6, 2014. Quality analyses were performed at zero, three and six months. Four different storage systems were adopted, namely: airtight environment, bags, horizontal aerated silo, and nonaerated silo.

In the airtight environment, closed "PET bottles" were used in storage; permeable nylon bags were used for the system in "bags"; in horizontal aerated silos, the system was used in the first three months; on September 17, 2013, it was connected at $21 \mathrm{~h} 50 \mathrm{minh}$ and disconnected at $05 \mathrm{~h} 53 \mathrm{~min}$; on September 24, 2013, it was connected at 21h:56min and disconnected at $07 \mathrm{~h}: 51 \mathrm{~min}$; on October 14, 2014 , it was connected at $22 \mathrm{~h}: 25 \mathrm{~min}$ and disconnected at 06h:15min;, on October 22, 2014, it was connected at $22 \mathrm{~h}: 10 \mathrm{~min}$ and disconnected at 07h:53min; on October 28, 2014, it was connected at $22 \mathrm{~h}: 08 \mathrm{~min}$ and disconnected at $06 \mathrm{~h}: 48 \mathrm{~min}$; on November 18, 2014, it was connected at $22 \mathrm{~h}: 40 \mathrm{~min}$ and disconnected at $07 \mathrm{~h}: 00 \mathrm{~min}$; and on November 29,2014 , it was connected at $21 \mathrm{~h}: 40 \mathrm{~min}$ and disconnected at $07 \mathrm{~h}: 28 \mathrm{~min}$, totaling seven uses of aeration in a total of 62 hours and 19 minutes; the system without aeration was not used for any control method.

For each storage system, corn grains were sampled in broken corn, whole corn, and normal corn without separating the parts and without impurities. For quality analysis, $200 \mathrm{~g}$ of the product were removed, forming a composite and representative sample of the batch according to the sampling system (BRASIL, 2012). The analysis carried out the following analyses: physical classification, physical properties, germination, electrical conductivity, crude protein, ash and acid value.

The physical classification of corn grains was performed from a simple working sample of 250 grams. This sample was passed through a sieve with circular holes, with five millimeters diameter for corn rating, prepared by the Ministry of Agriculture Livestock and Supply (BRASIL, 2012). Then, the parts of damaged grains, whole grains, broken grains, cracked, moldy, sprouted and fermented grains, foreign matter and classified impurities were weighed separately. There was also the presence of insects and toxic seeds in the sample. The percentage of each classified item was determined with respect to the original weight and the results were compared with standard corn grain sorting table (BRAZIL, 2012). Water content was determined by the standard oven method, $105^{\circ} \mathrm{C} \pm 5$ ${ }^{\circ} \mathrm{C}$ for $24 \mathrm{~h}$ with three replications as recommended (AOAC, 2000). The size of the seeds was determined by measuring the dimensions of length, width and thickness of each seed after drying. With the aid of a caliper with $0.01 \mathrm{~mm}$ resolution, 200 corn grains were measured for each temperature of the drying air. From the average of the measured dimensions the prediction interval was given (PI $=$ $X \pm$ ts). This interval was used to calculate the probabilities of a particular size of the grains were between the figures in the range obtained. 
The bulk density of corn grains was determined by the method of supplementary volume. Volumetric flasks $(10 \pm 0.04 \mathrm{~mL})$ and an analytical balance (accurate to $0.0001 \mathrm{~g}$ ) were used. Soybean oil as an additional liquid volume was used. During the determination, five samples were used for each temperature of the drying air, containing thirty seeds each. Density of the liquid (soybean oil) was obtained by the ratio between the mass and volume of the fluid from the balloon. Thus, the empty volumetric flask was weighed and then weighed again with the balloon oil to the 10 $\mathrm{mL}$ mark. Bulk density of corn grains was determined by placing each sample within a container of known volume and mass. Then, the volume of the flask was supplemented with soybean oil to the mark corresponding to the volume of $35.10 \mathrm{~mL}$ weighing again. Based on knowledge of the mass of the liquid used in the supplementary volume (obtained by subtraction), and its density, the volume occupied by grains was calculated. Bulk density of the grains was determined by the ratio between grain mass and volume, as shown in equation (1).

$$
p_{a p}=m / V
$$

where,

$\mathrm{p}_{\mathrm{ap}}$ : bulk density of the product, $\left(\mathrm{kg} \mathrm{m}^{-3}\right)$

m: product mass, $(\mathrm{kg})$

$\mathrm{V}$ : volume, $\left(\mathrm{mm}^{3}\right)$

To calculate the projected area of the estimated seed, equation was used (2).

$$
A_{p}=3.14 A B
$$

where,

$\mathrm{A}_{\mathrm{p}}$ : projected area, $\left(\mathrm{mm}^{2}\right)$

A: semi-major axis, (mm)

B: minor semi-axis, (mm)

Sphericity was calculated (MOHSENIN, 1986), based on the geometric mean of three perpendicular to the body axis relative to the major axis, according to equation (3).

$$
S={\frac{(\pi a b c)^{1 / 3}}{a}}^{1 / 3}
$$

where,

S: sphericity, dimensionless

a: major axis, $(\mathrm{mm})$

b: average axis, $(\mathrm{mm})$

c: minor axis, $(\mathrm{mm})$.

Circularity was determined according to equation (4) (MOHSENIN, 1986).

$$
C=A_{p} / A_{c}
$$

where,

$\mathrm{C}$ : is the circularity, dimensionless

$\mathrm{A}_{\mathrm{p}}$ : is the diameter of the largest circle inscribed in the projection of the object at rest, $\left(\mathrm{mm}^{2}\right)$

$\mathrm{A}_{c}$ : is the diameter of the smallest circumscribed circle in the projection of the object at rest, $\left(\mathrm{mm}^{2}\right)$

The form was determined by taking into account grain sphericity and roundness (MOHSENIN, 1986). Porosity was determined by the direct method (MOHSENIN, 1986), adding a known mass to the spaces of the granular liquid volume. Becker of $30 \mathrm{~mL}$ and a $50 \mathrm{~mL}$ burette was used and the liquid used is soybean oil. Porosity was calculated by equation 5 .

$$
\varepsilon=\left[1-\left(\frac{\rho_{a p}}{\rho_{u n}}\right)\right]
$$

where,

$$
\begin{aligned}
& \xi \text { : porosity, }(\%) \\
& \rho_{\text {ap }} \text { : bulk density apparent, }\left(\mathrm{kg} \mathrm{m}^{-3}\right)
\end{aligned}
$$$$
\rho_{\text {um }} \text { : specific mass unit, }\left(\mathrm{kg} \mathrm{m}^{-3}\right)
$$

The specific mass is estimated or actual unit, depending on the porosity and the bulk density of the grain mass in accordance with the following ratio, as shown in equation (6) (MOHSENIN, 1986).

$$
\rho_{\mu}=\rho_{a p} /(\xi-1)
$$

where,

$$
\begin{aligned}
& \rho_{\mu} \text { : specific mass unit, }\left(\mathrm{kg} \mathrm{m}^{-3}\right) \\
& \rho_{\text {ap }} \text { : specific mass apparent, }\left(\mathrm{kg} \mathrm{m}^{-3}\right) \\
& \xi \text { : porosity, }(\%)
\end{aligned}
$$

The thousand grain weight was determined by counting eight replicates of 100 grains and subsequent weighing them on an analytical balance (MOHSENIN, 1986). The results were multiplied by ten and expressed in grams. The volume $\left(\mathrm{V}_{\mathrm{g}}\right)$ of each grain was obtained during the drying process with the aid of a caliper according to expression (7), proposed by Mohsenin (1986):

$$
V g=\frac{\pi a b c}{6}
$$

where,
a: major axis of the grain, $(\mathrm{mm})$
b: mean axis of the grain, $(\mathrm{mm})$
c: minor axis of the grain, $(\mathrm{mm})$ 
The electrical conductivity test was conducted with corn grains according to the methodology described by Vieira and Krzyzanowski (1999). Fifty grains for 4 replicates of each treatment were weighed to an accuracy of two decimal places $(0.01 \mathrm{~g})$. The samples were placed in plastic cups to soak with $75 \mathrm{~mL}$ of deionised water and kept in a refrigerated chamber (BOD MA415) with controled temperature at $25 \pm 2{ }^{\circ} \mathrm{C}$ for 24 hours. The solutions containing the grains were gently stirred to uniformity of leachate, and immediately underwent reading on a portable CD850 "Instrutherm" digital conductivity meter. The results were divided by the mass of 50 grains and expressed in $\mu \mathrm{S} \mathrm{cm}^{-1} \mathrm{~g}^{-1}$ of grains.

According to the methodology described by AOAC (2000), the acid index of the sampled product was determined in three replications. The procedure was performed by placing $5 \mathrm{~g}$ of sample into a $250 \mathrm{~mL}$ beaker, adding $150 \mathrm{~mL}$ of ethanol and allowing it to stand for approximately 30 minutes, and agitating every 5 minutes. Then, the supernatant was filtered on filter paper $(0.5 \mathrm{~mm})$ into an Erlenmeyer flask. Next, another $100 \mathrm{~mL}$ of ethanol was added to the Erlenmeyer flask, leaving it at rest for 15 minutes with agitation every 5 minutes. It was filtered again, and 4 to 5 drops of phenolphthalein indicator solution (1\%) were added to the Erlenmeyer flask, and then titrated with $\mathrm{NaOH} 0.1 \mathrm{~N}$ until it turned into pink color. Equation 8 was used to calculate the acidity index in $\mathrm{mg}$ $\mathrm{NaOH} \mathrm{g}{ }^{-1}$

$$
A I=\frac{V x N x F x 40}{P}
$$

where,
AI: Acidity index
$\mathrm{V}$ : volume of $\mathrm{NaOH} 0.1 \mathrm{~N}$ titration spent, $(\mathrm{mL})$
$\mathrm{N}$ : normality
F: correction factor
$\mathrm{P}$ : weight of sample, (g)
40: equivalent weight of $\mathrm{NaOH}$

Crude protein was determined in three replicates for each sample from nitrogen, according to the Kjeldahl digestion method as described in AOAC (2000). This method was devised in 1983 and is based on three steps: digestion, distillation and titration. The process occurs by digesting the organic matter transformation of the sample with protein in ammonium sulfate $\left(\mathrm{NH}_{3} \mathrm{SO}_{4}\right)$ and the digesting action of the mixture (catalyst), sulfuric acid and heat. The organic material in the sample was decomposed with sulfuric acid and a catalyst where nitrogen was turned into ammonium salt. To determine protein digestion, $1 \mathrm{~g}$ of the sample was weighed in filter paper. Then, the sample was placed in the digester tube. In the digester tube, 1 pellet catalyst of copper $(\mathrm{Cu})$ and $15 \mathrm{~mL}$ of sulfuric acid $\left(\mathrm{H}_{2} \mathrm{SO}_{4}\right)$ were added. After addition of the products, the tubes were taken to the digester apparatus of protein at a temperature of $420{ }^{\circ} \mathrm{C}$, where it was only removed when it acquired a light green color (about 1 hour). After cooling the sample, $70 \mathrm{~mL}$ of distilled water was added in an Erlenmeyer flask with $30 \mathrm{~mL}$ boric acid. In the step of nitrogen distillation, ammonia was released from the ammonium salt by reaction with hydroxide. This occurred with the uptake of nitrogen, which was titrated and quantified. This procedure was carried out using a preheated tube distiller and a digester. In this tube, $\mathrm{NaOH}(40 \%)$ was added with the aid of a lever contained in a retort, proceeding distillation for about 4 minutes. After distillation, titration was performed with $\mathrm{H}_{2} \mathrm{SO}_{4} 0.1 \mathrm{~N}$ until it turned pink. The titrated volume was part of the calculation (equation 9) that resulted in the percentage of crude protein in the sample.

$$
C P=\frac{V_{1} \times 0.4 \times F \times 6.25}{P}
$$

where,

CP: percentage of crude protein, $(\%)$

$\mathrm{V}_{1}$ : titrated volume, $(\mathrm{mL})$

0.14 : gram equivalent nitrogen

F: correction factor solution of $\mathrm{H}_{2} \mathrm{SO}_{4} 0.1 \mathrm{~N}$

P: weight of sample, $(\mathrm{g})$

6.25: transformation of nitrogen into protein factor considering $16 \%$ of nitrogen.

Ash analysis was performed on a $2 \mathrm{~g}$ sample of ground corn grains, placed in tared porcelain crucibles at $100{ }^{\circ} \mathrm{C}$ in an oven and calcined at 600 ${ }^{\circ} \mathrm{C}$ in a muffle. The sample was placed in the oven for 4 hours at $600{ }^{\circ} \mathrm{C}$. Then, the sample was allowed to cool in desiccators until room temperature and then weighed (AOAC, 2000). After calcinations, ash content was determined by weighing the difference between the mass of the previously calcined empty crucible and the mass of the crucible and calcite residue, considering the mass of the fresh sample.

The germination test was conducted with four replicates of 30 seeds of each treatment, in rolls of "Germitest" paper towel in a "Mangesdorf" germinator set to maintain a constant temperature of $25 \pm 2{ }^{\circ} \mathrm{C}$. The amount of water added was equivalent to 2.5 times the dry mass of the substrate, aiming at the adequate wetting and, consequently, the standardization of the test. The interpretations were made as of the 4th day after sowing until the 
10th day according to the criteria set out in the Rules for Seed Analysis (BRASIL, 2009).

The experimental design was completely randomized $(4 \times 3)$, four storage forms (airtight storage, bags, non-aerated silo, and aerated silo), three types of corn mass (normal corn, whole corn, broken corn). Analysis of variance and comparison of means by Tukey's test at $5 \%$ probability were performed.

\section{RESULTS AND DISCUSSION}

The results of the physical properties of corn grains, due to their different shapes, storage times and quality of corn, showed significant difference at $5 \%$ probability. Table 1 shows that the storage of corn grains with application of the aeration system and the airtight system preserved the physical characteristics of corn grains. The greatest physical changes occurred in the grain storage without application of aeration and bags. Regardless of the system used, storage time influenced the physical characteristics of corn grains. Table 1 shows the mass of the whole corn grains, preserved the physical characteristics, regardless of the shape and storage.

Table 1. Physical properties of corn grains stored under different forms and storage times.

\begin{tabular}{|c|c|c|c|c|c|c|c|c|c|}
\hline \multirow{3}{*}{ Storage } & \multicolumn{3}{|c|}{ Whole corn } & \multicolumn{3}{|c|}{ Cracked corn } & \multicolumn{3}{|c|}{ Normal corn } \\
\hline & \multicolumn{3}{|c|}{ Time (months) } & \multicolumn{3}{|c|}{ Time (months) } & \multicolumn{3}{|c|}{ Time (months) } \\
\hline & Zero & Three & Six & Zero & Three & Six & Zero & Three & Six \\
\hline \multicolumn{10}{|c|}{ Length $(\mathrm{mm})^{*}$} \\
\hline Airtight & $11.89 \mathrm{aC}$ & $11.51 \mathrm{bB}$ & $11.25 \mathrm{bA}$ & $9.15 \mathrm{aA}$ & $10.54 \mathrm{cC}$ & $09.61 \mathrm{bB}$ & $11.53 \mathrm{aB}$ & $11.33 \mathrm{bA}$ & $11.30 \mathrm{bA}$ \\
\hline Bag & $11.89 \mathrm{aB}$ & $11.46 \mathrm{bA}$ & $11.52 \mathrm{bA}$ & $9.15 \mathrm{aA}$ & $09.15 \mathrm{bA}$ & $12.23 \mathrm{~dB}$ & $11.53 \mathrm{aB}$ & $11.40 \mathrm{bB}$ & $11.43 \mathrm{cB}$ \\
\hline Non-aerated & $11.89 \mathrm{aC}$ & $11.51 \mathrm{bB}$ & $11.38 \mathrm{bA}$ & $9.15 \mathrm{aA}$ & $10.31 \mathrm{cC}$ & $10.21 \mathrm{cB}$ & $11.53 \mathrm{aB}$ & $11.35 \mathrm{bA}$ & $11.48 \mathrm{cB}$ \\
\hline Aerated & $11.89 \mathrm{aC}$ & $10.70 \mathrm{aA}$ & $10.98 \mathrm{aB}$ & $9.15 \mathrm{aB}$ & $08.01 \mathrm{aA}$ & $09.17 \mathrm{aB}$ & $11.53 \mathrm{aA}$ & $10.56 \mathrm{aA}$ & $10.93 \mathrm{aB}$ \\
\hline \multicolumn{10}{|c|}{ Width $(\mathrm{mm})^{*}$} \\
\hline Airtight & $7.98 \mathrm{aC}$ & $7.75 \mathrm{aB}$ & $7.68 \mathrm{aA}$ & $6.94 \mathrm{aB}$ & $6.87 \mathrm{cA}$ & $6.84 \mathrm{aA}$ & $7.94 \mathrm{aB}$ & $7.79 \mathrm{bA}$ & $7.74 \mathrm{bA}$ \\
\hline Bag & $7.98 \mathrm{aB}$ & $7.72 \mathrm{aA}$ & $7.75 \mathrm{bA}$ & $6.94 \mathrm{aC}$ & $6.31 \mathrm{bA}$ & $6.76 \mathrm{aB}$ & $7.94 \mathrm{aB}$ & $7.82 \mathrm{aA}$ & $7.83 \mathrm{cA}$ \\
\hline Non-aerated & $7.98 \mathrm{aB}$ & $7.89 \mathrm{bA}$ & $7.84 \mathrm{cA}$ & $6.94 \mathrm{aA}$ & $7.28 \mathrm{~dB}$ & $7.03 \mathrm{bA}$ & $7.94 \mathrm{aC}$ & $7.81 \mathrm{aB}$ & $7.72 \mathrm{bA}$ \\
\hline Aerated & $7.98 \mathrm{aB}$ & $8.18 \mathrm{cC}$ & $7.82 \mathrm{cA}$ & $6.94 \mathrm{aC}$ & $5.94 \mathrm{aA}$ & $6.79 \mathrm{aB}$ & $7.94 \mathrm{aB}$ & $8.02 \mathrm{bB}$ & $7.66 \mathrm{aA}$ \\
\hline \multicolumn{10}{|c|}{ Thickness $(\mathrm{mm})^{*}$} \\
\hline Airtight & $7.98 \mathrm{aB}$ & $4.40 \mathrm{aA}$ & $4.36 \mathrm{aA}$ & $4.58 \mathrm{cA}$ & $4.86 \mathrm{aB}$ & $4.46 \mathrm{cA}$ & $4.90 \mathrm{dD}$ & $4.50 \mathrm{aA}$ & $4.59 \mathrm{cB}$ \\
\hline Bag & $7.98 \mathrm{aB}$ & $4.40 \mathrm{aA}$ & $4.43 \mathrm{bA}$ & $4.44 \mathrm{bB}$ & $4.86 \mathrm{aC}$ & $4.19 \mathrm{bA}$ & $4.37 \mathrm{bB}$ & $4.50 \mathrm{aA}$ & $4.39 \mathrm{aA}$ \\
\hline Non-aerated & $7.98 \mathrm{aC}$ & $4.40 \mathrm{aA}$ & $4.64 \mathrm{cB}$ & $4.49 \mathrm{bA}$ & $4.86 \mathrm{aB}$ & $4.93 \mathrm{~dB}$ & $4.77 \mathrm{cC}$ & $4.50 \mathrm{aA}$ & $4.63 \mathrm{~dB}$ \\
\hline Aerated & $7.98 \mathrm{aC}$ & $4.40 \mathrm{aA}$ & $4.60 \mathrm{cB}$ & $4.21 \mathrm{aB}$ & $4.86 \mathrm{aC}$ & $3.83 \mathrm{aA}$ & $4.05 \mathrm{aA}$ & $4.50 \mathrm{aA}$ & $4.49 \mathrm{bB}$ \\
\hline \multicolumn{10}{|c|}{ Volume $\left(\mathrm{mm}^{3}\right)^{*}$} \\
\hline Airtight & $218 \mathrm{aB}$ & $202 \mathrm{aA}$ & $206 \mathrm{bA}$ & $160 \mathrm{aA}$ & $169 \mathrm{cB}$ & $171 \mathrm{bB}$ & $215 \mathrm{aC}$ & $210 \mathrm{bB}$ & $207 \mathrm{bA}$ \\
\hline Bag & $218 \mathrm{aB}$ & $204 \mathrm{aA}$ & $206 \mathrm{bA}$ & $160 \mathrm{aB}$ & $129 \mathrm{bA}$ & $190 \mathrm{cC}$ & $215 \mathrm{aB}$ & $203 \mathrm{aA}$ & 206 bA \\
\hline Non-aerated & $218 \mathrm{aB}$ & $219 \mathrm{cB}$ & $208 \mathrm{bA}$ & $160 \mathrm{aA}$ & $191 \mathrm{dC}$ & $177 \mathrm{bB}$ & $215 \mathrm{aB}$ & $213 \mathrm{bB}$ & $208 \mathrm{bA}$ \\
\hline Aerated & $218 \mathrm{aC}$ & $208 \mathrm{bB}$ & $188 \mathrm{aA}$ & $160 \mathrm{aC}$ & $097 \mathrm{aA}$ & $132 \mathrm{aB}$ & $215 \mathrm{aC}$ & $199 \mathrm{aB}$ & $187 \mathrm{aA}$ \\
\hline \multicolumn{10}{|c|}{ Projected area $\left(\mathrm{mm}^{2}\right)^{*}$} \\
\hline Airtight & $40.99 \mathrm{aA}$ & $39.07 \mathrm{aA}$ & $40.24 \mathrm{cA}$ & $34.61 \mathrm{aA}$ & $36.95 \mathrm{cB}$ & $36.97 \mathrm{bB}$ & $40.52 \mathrm{aA}$ & $40.53 \mathrm{cA}$ & $40.20 \mathrm{cA}$ \\
\hline Bag & $40.99 \mathrm{aA}$ & $39.72 \mathrm{aA}$ & $39.94 \mathrm{bA}$ & $34.61 \mathrm{aB}$ & $30.04 \mathrm{bA}$ & $40.57 \mathrm{cC}$ & $40.52 \mathrm{aA}$ & $38.97 \mathrm{bA}$ & $39.46 \mathrm{bA}$ \\
\hline Non-aerated & $40.99 \mathrm{aA}$ & $41.61 \mathrm{bA}$ & $39.90 \mathrm{bA}$ & $34.61 \mathrm{aA}$ & $39.43 \mathrm{dC}$ & $37.73 \mathrm{bB}$ & $40.52 \mathrm{aA}$ & $40.97 \mathrm{cA}$ & $40.58 \mathrm{cA}$ \\
\hline Aerated & $40.99 \mathrm{aC}$ & $38.13 \mathrm{aB}$ & $36.07 \mathrm{aA}$ & $34.61 \mathrm{aC}$ & $24.22 \mathrm{aA}$ & $29.18 \mathrm{aB}$ & $40.52 \mathrm{aB}$ & $36.95 \mathrm{aA}$ & $36.39 \mathrm{aA}$ \\
\hline \multicolumn{10}{|c|}{ Sphericity $(\%)^{*}$} \\
\hline Airtight & $0.63 \mathrm{aA}$ & $0.64 \mathrm{aA}$ & $0.65 \mathrm{aA}$ & $0.74 \mathrm{aC}$ & $0.65 \mathrm{aA}$ & $0.71 \mathrm{bB}$ & $0.65 \mathrm{aA}$ & $0.66 \mathrm{bA}$ & $0.65 \mathrm{aA}$ \\
\hline Bag & $0.63 \mathrm{aA}$ & $0.64 \mathrm{aA}$ & $0.64 \mathrm{aA}$ & $0.74 \mathrm{aC}$ & $0.69 \mathrm{bB}$ & $0.63 \mathrm{aA}$ & $0.65 \mathrm{aA}$ & $0.64 \mathrm{cA}$ & $0.64 \mathrm{aA}$ \\
\hline Non-aerated & $0.63 \mathrm{aA}$ & $0.65 \mathrm{aA}$ & $0.65 \mathrm{aA}$ & $0.74 \mathrm{aB}$ & $0.70 \mathrm{bA}$ & $0.69 \mathrm{bA}$ & $0.65 \mathrm{aA}$ & $0.66 \mathrm{bA}$ & $0.65 \mathrm{aA}$ \\
\hline Aerated & $0.63 \mathrm{aA}$ & $0.69 \mathrm{bA}$ & $0.65 \mathrm{aA}$ & $0.74 \mathrm{aB}$ & $0.72 \mathrm{bB}$ & $0.70 \mathrm{bA}$ & $0.65 \mathrm{aA}$ & $0.69 \mathrm{cB}$ & $0.66 \mathrm{aA}$ \\
\hline \multicolumn{10}{|c|}{ Circularity $(\%)^{*}$} \\
\hline Airtight & $0.79 \mathrm{aB}$ & $0.69 \mathrm{aA}$ & $0.69 \mathrm{bA}$ & $0.72 \mathrm{aA}$ & $0.70 \mathrm{cA}$ & $0.96 \mathrm{~dB}$ & $0.85 \mathrm{aB}$ & $0.67 \mathrm{bA}$ & $0.70 \mathrm{bA}$ \\
\hline Bag & $0.79 \mathrm{aC}$ & $0.59 \mathrm{cA}$ & $0.74 \mathrm{cB}$ & $0.72 \mathrm{aC}$ & $0.55 \mathrm{aA}$ & $0.82 \mathrm{cB}$ & $0.85 \mathrm{aC}$ & $0.54 \mathrm{aA}$ & $0.68 \mathrm{bB}$ \\
\hline Non-aerated & $0.79 \mathrm{aC}$ & $0.67 \mathrm{aA}$ & $0.73 \mathrm{cB}$ & $0.72 \mathrm{aB}$ & $0.65 \mathrm{bA}$ & $0.75 \mathrm{bB}$ & $0.85 \mathrm{aC}$ & $0.74 \mathrm{cB}$ & $0.68 \mathrm{bA}$ \\
\hline Aerated & $0.79 \mathrm{aC}$ & $0.61 \mathrm{bB}$ & $0.59 \mathrm{aA}$ & $0.72 \mathrm{aC}$ & $0.64 \mathrm{bB}$ & $0.55 \mathrm{aA}$ & $0.85 \mathrm{aB}$ & $0.62 \mathrm{bA}$ & $0.65 \mathrm{aA}$ \\
\hline
\end{tabular}

*Means followed by the capital letter in the line for each storage time and lowercase in the column for each storage form, do not differ at $5 \%$ probability.

The conservation of the physical and mechanical properties is important for storage, for design purposes, construction and operation of various equipment used in the main post-harvest operations (PUZZI, 2010; CORADI et al., 2011; SCHUH et al., 2011; SANTOS et al., 2012).

In the specific case of maize, equipment and operations, when sized, can hardly generate kernel 
cracking and, consequently, a reduction in market prices. In order to minimize production costs for greater competitiveness and improve the quality of the final product, the determination and the knowledge of the behavior of corn grain properties are the main factors contributing to the proper development processes and simulations aimed at improving the production system of this crop (PUZZI, 2010; SANTOS et al., 2012; COSTA et al., 2013). Several factors can interfere with bulk density, porosity and weight of the corn kernels from factors associated with farming, such as planting time, incidence of sunlight or excessive shading, temperature, planting density, harvest, transport, drying and storing (MAZZUCO et al., 2002), and type of hybrid and physiological maturity. Table 2 shows that the porosity of the grains has increased over storage time, regardless of storage medium.

Table 2. Alterations in the physical mass of corn grains stored under different forms and storage times.

\begin{tabular}{|c|c|c|c|c|c|c|c|c|c|}
\hline \multirow[b]{3}{*}{ Storage } & \multicolumn{3}{|c|}{ Whole corn } & \multicolumn{3}{|c|}{ Cracked corn } & \multicolumn{3}{|c|}{ Normal corn } \\
\hline & \multicolumn{3}{|c|}{ Time (months) } & \multicolumn{3}{|c|}{ Time (months) } & \multicolumn{3}{|c|}{ Time (months) } \\
\hline & Zero & Three & Six & Zero & Three & Six & Zero & Three & Six \\
\hline \multicolumn{10}{|c|}{ Porosity $(\%)^{*}$} \\
\hline Airtight & $46.25 \mathrm{aA}$ & $66.67 \mathrm{bB}$ & $65.47 \mathrm{aB}$ & $44.24 \mathrm{aA}$ & $65.68 \mathrm{bC}$ & $64.06 \mathrm{bB}$ & $46.16 \mathrm{aA}$ & $66.94 \mathrm{bcB}$ & $66.38 \mathrm{bB}$ \\
\hline Bag & $46.25 \mathrm{aA}$ & $65.82 \mathrm{abB}$ & $65.87 \mathrm{aB}$ & $44.24 \mathrm{aA}$ & $61.55 \mathrm{aC}$ & $58.97 \mathrm{aB}$ & $46.16 \mathrm{aA}$ & $67.96 \mathrm{cC}$ & $66.49 \mathrm{bB}$ \\
\hline Non-aerated & $46.25 \mathrm{aA}$ & $66.59 \mathrm{bB}$ & $66.16 \mathrm{aB}$ & $44.24 \mathrm{aA}$ & $64.35 \mathrm{bB}$ & $63.96 \mathrm{bB}$ & $46.16 \mathrm{aA}$ & 65.98abB & $67.10 \mathrm{bB}$ \\
\hline Aerated & $46.25 \mathrm{aA}$ & $64.91 \mathrm{aB}$ & $65.15 \mathrm{aB}$ & $44.24 \mathrm{aA}$ & $61.55 \mathrm{aB}$ & $60.45 \mathrm{aB}$ & $46.16 \mathrm{aA}$ & $65.20 \mathrm{aB}$ & $64.03 \mathrm{aB}$ \\
\hline \multicolumn{10}{|c|}{ Bulk density apparent $\left(\mathrm{kg} \mathrm{m}^{-3}\right)^{*}$} \\
\hline Airtight & $750 \mathrm{aA}$ & $790 \mathrm{bB}$ & $810 \mathrm{cC}$ & 740 aA & $760 \mathrm{~dB}$ & $770 \mathrm{dC}$ & $760 \mathrm{aA}$ & $770 \mathrm{aB}$ & $800 \mathrm{cC}$ \\
\hline Bag & $750 \mathrm{aA}$ & $790 \mathrm{bB}$ & $810 \mathrm{cC}$ & $740 \mathrm{aC}$ & $690 \mathrm{aA}$ & $700 \mathrm{aB}$ & $760 \mathrm{aA}$ & $780 \mathrm{bB}$ & $810 \mathrm{dC}$ \\
\hline Non-aerated & $750 \mathrm{aA}$ & $780 \mathrm{aB}$ & $790 \mathrm{aC}$ & $740 \mathrm{aA}$ & $750 \mathrm{cB}$ & $750 \mathrm{cC}$ & $760 \mathrm{aA}$ & $770 \mathrm{aB}$ & $790 \mathrm{bC}$ \\
\hline Aerated & $750 \mathrm{aA}$ & $780 \mathrm{aB}$ & $800 \mathrm{bC}$ & $740 \mathrm{aB}$ & $730 \mathrm{bA}$ & $730 \mathrm{bA}$ & $760 \mathrm{aA}$ & $770 \mathrm{aB}$ & $770 \mathrm{aB}$ \\
\hline \multicolumn{10}{|c|}{ Thousand kernel weight $(\mathrm{g})^{*}$} \\
\hline Airtight & $298 \mathrm{aB}$ & $300 \mathrm{cB}$ & $289 \mathrm{bA}$ & $220 \mathrm{aB}$ & $216 \mathrm{cA}$ & $220 \mathrm{bB}$ & $291 \mathrm{aA}$ & $295 \mathrm{bB}$ & $289 \mathrm{bA}$ \\
\hline Bag & $298 \mathrm{aA}$ & $305 \mathrm{bB}$ & $298 \mathrm{cA}$ & $220 \mathrm{aC}$ & $150 \mathrm{bB}$ & $140 \mathrm{aA}$ & $291 \mathrm{aA}$ & $300 \mathrm{cB}$ & $295 \mathrm{bA}$ \\
\hline Non-aerated & $298 \mathrm{aB}$ & $299 \mathrm{aB}$ & $294 \mathrm{aA}$ & $220 \mathrm{aB}$ & $234 \mathrm{dA}$ & $230 \mathrm{cA}$ & $291 \mathrm{aA}$ & $301 \mathrm{cB}$ & $300 \mathrm{cB}$ \\
\hline Aerated & $298 \mathrm{aA}$ & $312 \mathrm{~dB}$ & $294 \mathrm{aA}$ & $220 \mathrm{aC}$ & $125 \mathrm{aA}$ & $143 \mathrm{aB}$ & $291 \mathrm{aC}$ & $283 \mathrm{aB}$ & $272 \mathrm{aA}$ \\
\hline
\end{tabular}

*Means followed by the capital letter in the line for each storage time and lowercase in the column for each storage form, do not differ at $5 \%$ probability.

Between storage systems, there were no significant differences in porosity values. According to Puzzi (2010), the porosity of the mass of wheat, rice and corn usually lies in the range $40-45 \%$ of the intergranular spaces, given the results obtained at time zero storage, and also showing the effects of storage time. The analysis of the results of bulk density (Table 2) showed that increased storage time reduced the grain mass to all forms of storage. The worst density results were observed in storage silos without an aeration system. While airtight storage was the one that best preserved the initial weight of the grains (thousand grain weight) over time, the storage system in sacks, followed by the storage silo with an aeration system. The results are consistent with most agricultural grains. According to Shiroma et al. (2010), bulk density is an important parameter to consider in receiving grain. Commonly used by agribusiness, the determination of the apparent density is one evaluation criterion for product quality, and it helps determine market prices. Apparent density also corresponds to the weight of the grain mass contained in a given volume, expressed in kilograms per cubic meter $\left(\mathrm{kg} \mathrm{m}^{-3}\right)$ (SHIROMA et al., 2010). Information on porosity, bulk density and thousand kernel weight is considered of great importance for studies involving heat and mass transfer and air movement in granular masses. Together with water content, volume, density, and porosity, these data are basic parameters for the study of drying conditions and storage of agricultural products and, consequently, they facilitate the prediction of loss of quality of the material until time of marketing .

According to the results (Table 3), there was a significant difference in the percentage of germination and electrical conductivity values of stored maize grain, due to the triple interaction between types of grain, shape and storage time.

In general, there was a decrease in the percentage of germination of corn kernels stored over time, regardless of storage medium, and the worst results were observed for broken corn kernels. However, when comparing shapes, grains stored hermetically showed higher germination percentages, over storage time. In the case of airtight storage, Guberac et al. (2003) evaluated the behavior of the physiological quality of seeds of wheat, oats (Avena sativa L.) and maize (Zea mays L.) stored in airtight glass containers for five years, 
with controlled temperature and relative humidity air. The authors found that both wheat and oats showed no significant variation in germination percentag, but the corn kernels showed a significant decrease after five years of storage.

Table 3. Physical quality of corn grains stored under different forms and storage conditions.

\begin{tabular}{|c|c|c|c|c|c|c|c|c|c|}
\hline & \multicolumn{3}{|c|}{ Whole corn } & \multicolumn{3}{|c|}{ Cracked corn } & \multicolumn{3}{|c|}{ Normal corn } \\
\hline & \multicolumn{3}{|c|}{ Time (months) } & \multicolumn{3}{|c|}{ Time (months) } & \multicolumn{3}{|c|}{ Time (months) } \\
\hline Storage & Zero & Three & Six & Zero & Three & Six & Zero & Three & Six \\
\hline \multicolumn{10}{|c|}{ Electrical conductivity $\left(\mu \mathrm{S} \mathrm{cm}^{-1} \mathrm{~g}^{-1}\right)^{*}$} \\
\hline Airtight & $114 \mathrm{aA}$ & $148 \mathrm{bC}$ & $138 \mathrm{aB}$ & $678 \mathrm{aC}$ & $511 \mathrm{aB}$ & $428 \mathrm{aA}$ & $169 \mathrm{aB}$ & $161 \mathrm{aB}$ & $150 \mathrm{aA}$ \\
\hline Bag & $114 \mathrm{aA}$ & $133 \mathrm{aB}$ & $145 \mathrm{bC}$ & $678 \mathrm{aB}$ & 658 bA & 781 bC & $169 \mathrm{aB}$ & $156 \mathrm{aA}$ & $167 \mathrm{bB}$ \\
\hline Non-aerated & $114 \mathrm{aA}$ & $157 \mathrm{cB}$ & $209 \mathrm{cC}$ & $678 \mathrm{aC}$ & $351 \mathrm{aA}$ & 466 cB & $169 \mathrm{aA}$ & $170 \mathrm{cA}$ & $168 \mathrm{bA}$ \\
\hline Aerated & $114 \mathrm{aA}$ & $335 \mathrm{~dB}$ & $329 \mathrm{~dB}$ & $678 \mathrm{aA}$ & $955 \mathrm{cB}$ & $961 \mathrm{~dB}$ & $169 \mathrm{aA}$ & $317 \mathrm{~dB}$ & $429 \mathrm{cC}$ \\
\hline \multicolumn{10}{|c|}{ Germination $(\%)^{*}$} \\
\hline Airtight & $97.50 \mathrm{aA}$ & $98.50 \mathrm{bA}$ & $98.50 \mathrm{bA}$ & $40.50 \mathrm{aA}$ & $54.00 \mathrm{dC}$ & $39.50 \mathrm{cB}$ & $87.50 \mathrm{aA}$ & $97.50 \mathrm{bC}$ & $95.00 \mathrm{bB}$ \\
\hline Bag & $97.50 \mathrm{aA}$ & $97.50 \mathrm{bA}$ & $96.50 \mathrm{bA}$ & $40.50 \mathrm{aB}$ & $47.50 \mathrm{cB}$ & $25.50 \mathrm{bA}$ & $87.50 \mathrm{aA}$ & $94.50 \mathrm{aB}$ & $94.50 \mathrm{bB}$ \\
\hline Non-aerated & $97.50 \mathrm{aB}$ & $96.00 \mathrm{bB}$ & $94.00 \mathrm{aA}$ & $40.50 \mathrm{aB}$ & $37.50 \mathrm{bA}$ & $44.50 \mathrm{~dB}$ & $87.50 \mathrm{aA}$ & $95.00 \mathrm{aB}$ & $95.00 \mathrm{bB}$ \\
\hline Aerated & $97.50 \mathrm{aB}$ & $92.00 \mathrm{aA}$ & $93.50 \mathrm{aA}$ & $40.50 \mathrm{aC}$ & $08.00 \mathrm{aB}$ & $05.50 \mathrm{aA}$ & $87.50 \mathrm{aC}$ & $44.50 \mathrm{aB}$ & $21.00 \mathrm{aA}$ \\
\hline
\end{tabular}

*Means followed by the capital letter in the line for each storage time and lowercase in the column for each storage form, do not differ at $5 \%$ probability.

It is observed that in any form of storage, electrical conductivity of the solution increased over time (Table 3). The grains stored with the aeration system were the most affected, while the airtight form of grain storage had lower electrical conductivity values, regardless of type of corn. Considering the types of grains, the difference was notorious for electrical conductivity values in stored broken grains, which indicates a faster process of deterioration of the cell wall membrane.

Table 2 shows the behavior of electrical conductivity of the solution containing corn kernels stored hermetically according to this variation of germination percentage. Grains with higher electric conductivity are characterized by having higher cell membrane degradation and consequently lower force (FERRARI FILHO et al., 2011). According to Coradi et al. (2011), reading the electrical conductivity of the solution containing the seeds can be used to evaluate this effect, since the conductivity value is related to the amount of ions leached into solution, which is directly associated with cell membrane integrity; poorly structured damaged cells and membranes are generally associated with seed deterioration and, therefore, the low vigor. The lowest values, corresponding to the lowest level of ions indicate high physiological vigor and show less intense disorganization of the cell membrane system (PANOBIANCO et al., 2007; FESSEL et al., 2010).

Figures 1, 2, 3 and 4 show significant changes $(\mathrm{P}<0.05)$ for water content, protein, ash content, and acid value of corn grains as a function of grain shape, storage time and quality of maize. Figure 1 shows that there was an increase in water content over time of storage, regardless of type of corn. Storage with aeration and low quality grains (broken) caused greater increase in water content, while there was no difference between types of grains in storage without aeration. In storage in sacks, batch to batch consistency of corn prevailed on increasing water content; it can be seen in lots of whole grains and broken grains. In airtight storage, there was a higher increase in water levels in broken grains.

The factor of variation was most forms of storage, when grain moisture contents were lower in the airtight system (Figure 1). Among the types of grains, variations in water content were similar, namely, the storage environment prevailing on the quality of the grains remain similar between normal batches and broken grains.

Figure 2 shows the results of crude protein in corn kernels. It was found that the grain storage bins with aeration and airtight system gave the best results for crude protein. Among the types of grains, the percentage of protein was significantly high for lots with whole grains. However, storage time was the strongest influence on reduction of protein percentage for whole corn grains, regardless of storage form. 

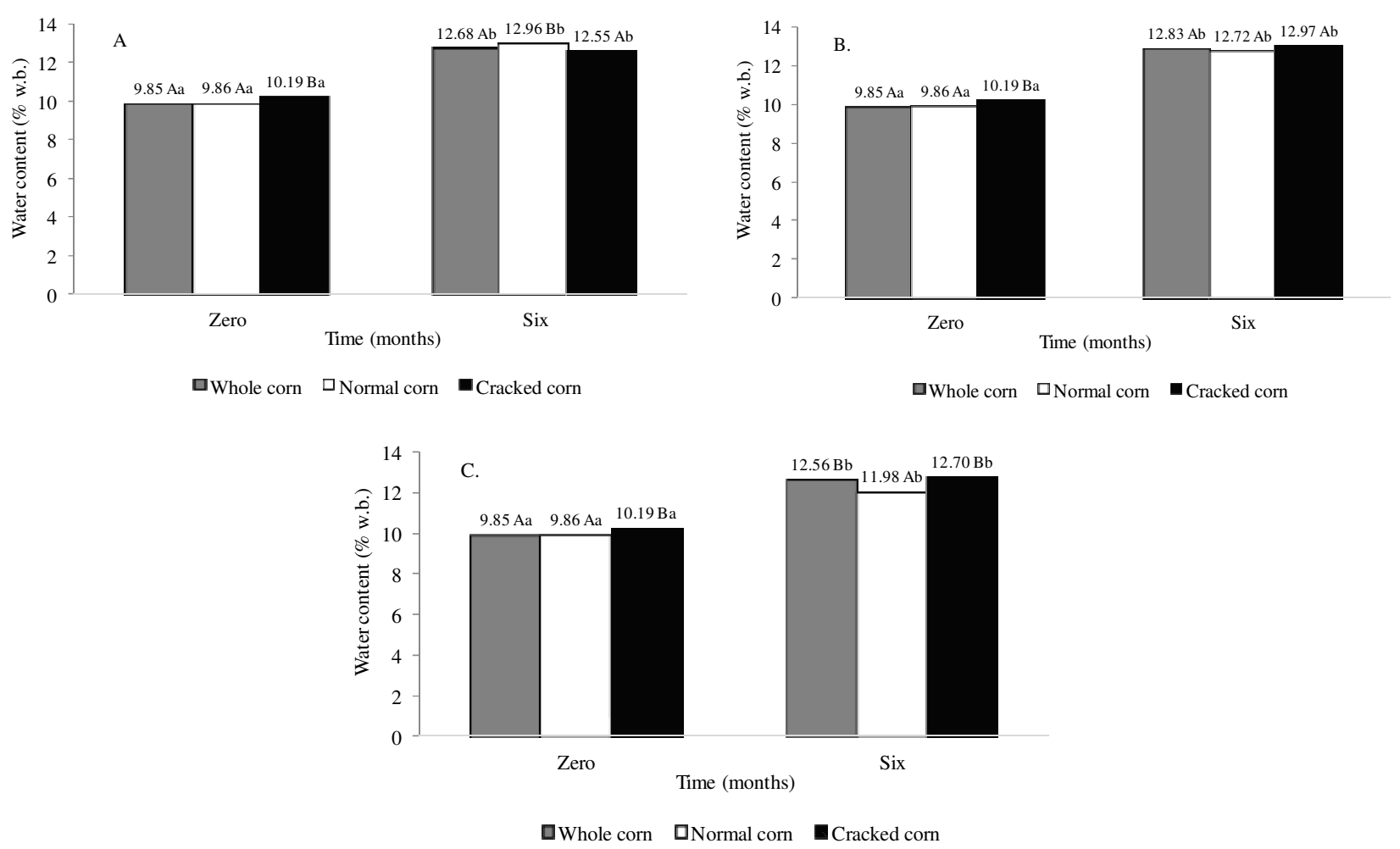

*Means followed by the capital letter in the line for each storage time and lowercase in the column for each corn type, do not differ at $5 \%$ probability

Figure 1. Water content (\% w.b.) in maize stored: aerated (A), non-aerated (B), conventional storage in bags (C), airtight storage (D).
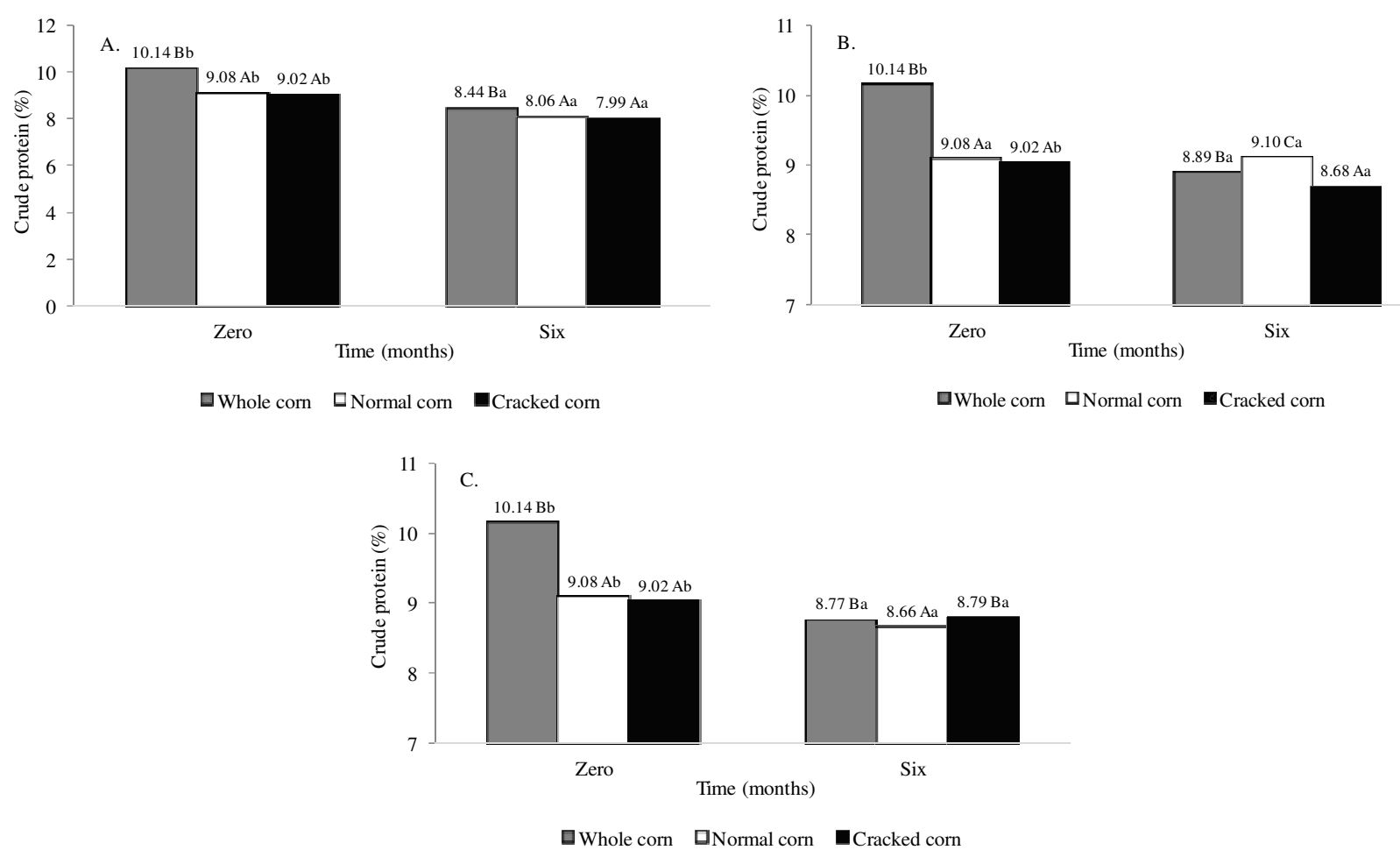

*Means followed by the capital letter in the line for each storage time and lowercase in the column for each corn type, do not differ at $5 \%$ probability

Figure 2. Determination of crude protein (\%) in maize stored: aerated (A), non-aerated (B); conventional in bags (C), airtight storage (D). 

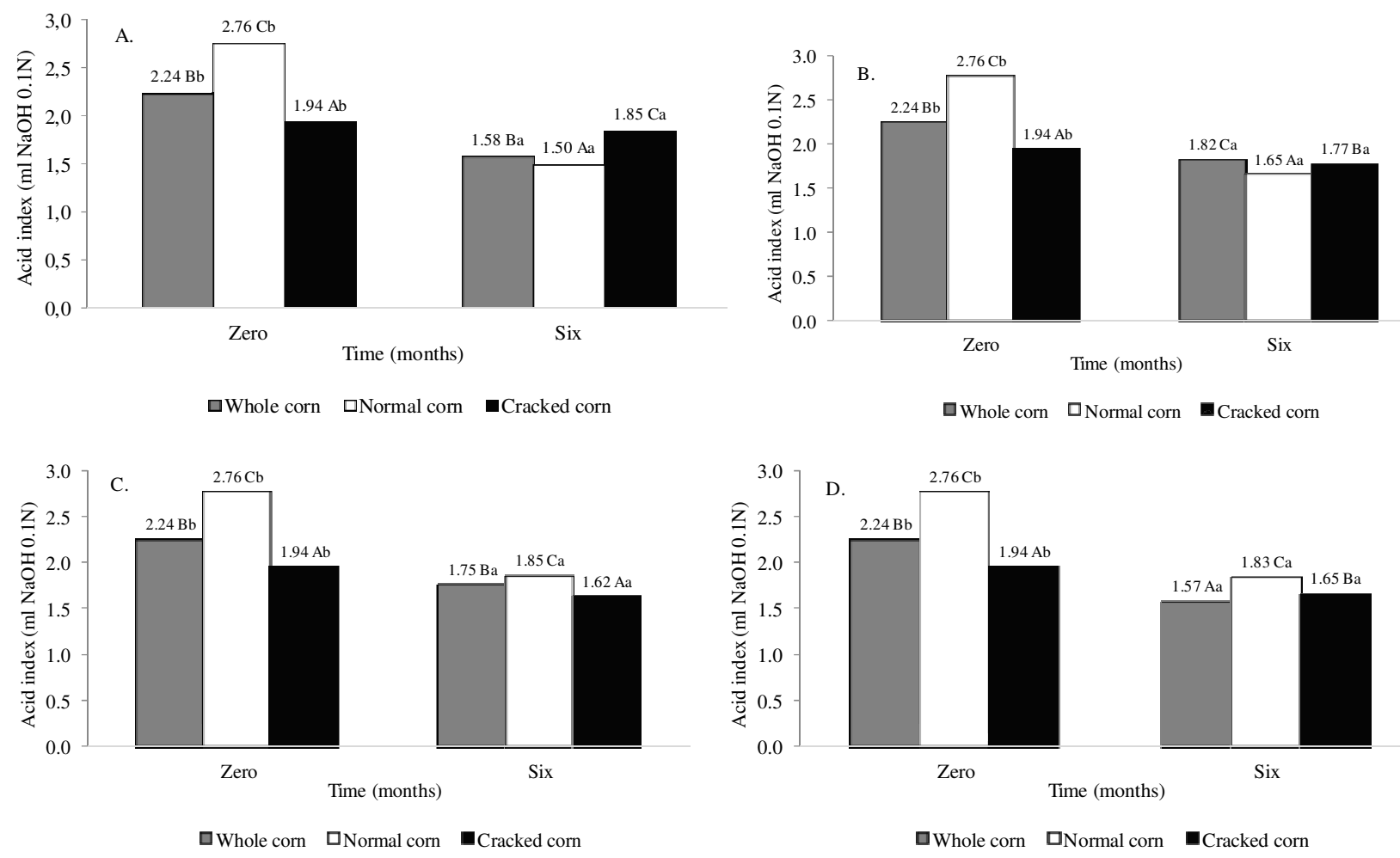

*Means followed by the capital letter in the line for each storage time and lowercase in the column for each corn type, do not differ at $5 \%$ probability.

Figure 3. Index acidity ( $\mathrm{mL} \mathrm{NaOH} 1 \mathrm{~N})$ in corn stored: aerated (A), non-aerated (B), conventional in bags (C), airtight storage (D).
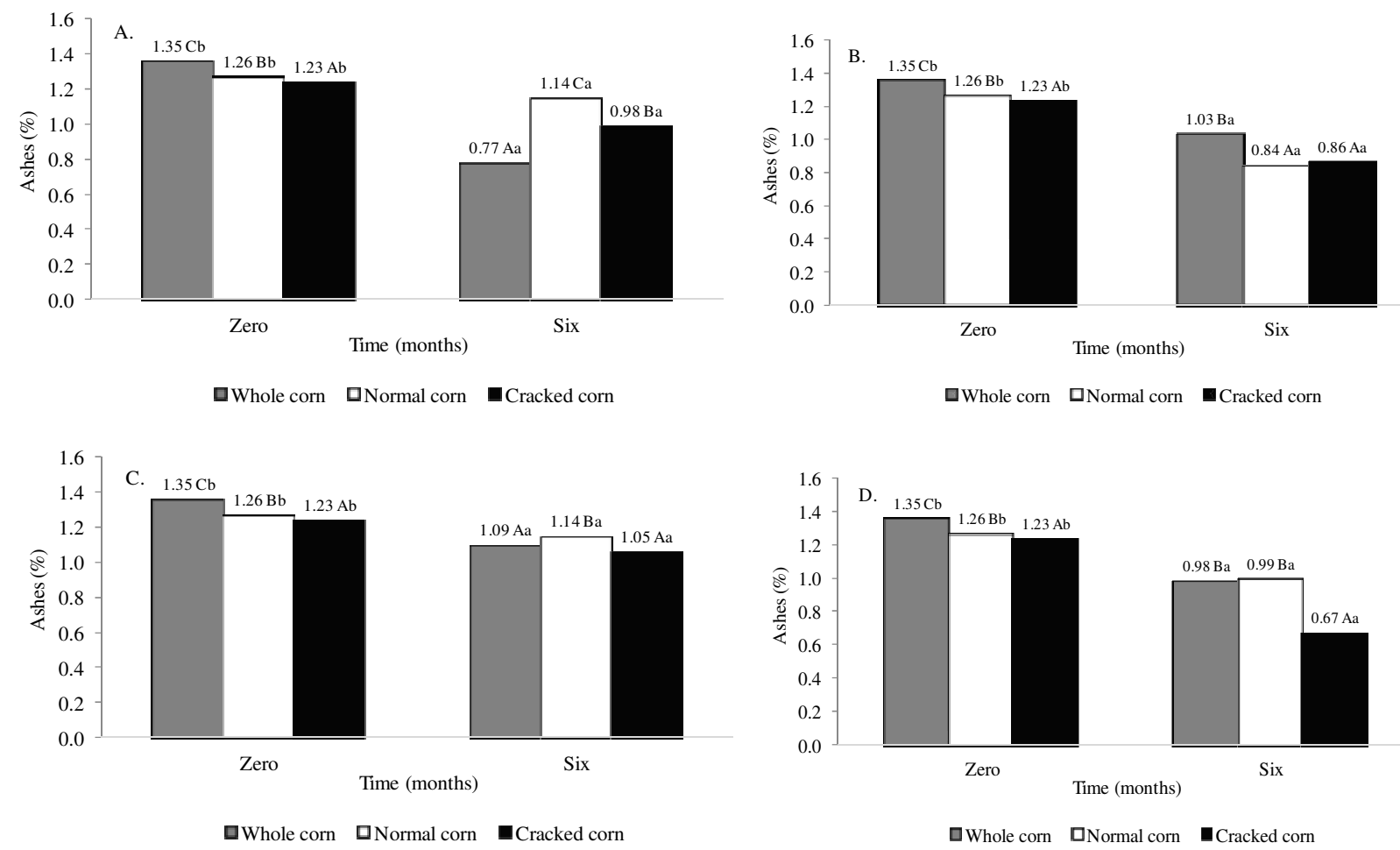

*Means followed by the capital letter in the line for each storage time and lowercase in the column for each corn type, do not differ at $5 \%$ probability.

Figure 4. Percentage of ash (\%) in corn stored: aerated (A), non-aerated (B), conventional in bags (C), airtight storage (D). 
The maintenance of crude protein of broken corn kernels and mixed, longer and final values equal in not airtight system occurred, possibly by the fact that, when the analysis of crude protein is performed, fungal protein is also analyzed, measured along with the raw grain protein. Thus, the specific content is the sum totals of grain protein and fungal protein (SCHUH et al., 2011). These results show that storage time had little influence on the storage forms when analyzing the mass of grains broken and mixed differently for whole grains. According to these authors, crude protein serves as a primary source of carbon and nitrogen for growth and metabolism of fungi. Fungal growth can occur, even at low levels, in the airtight system for oxygen, and there can also be an initial increase in the crude protein of the grain, but to a lesser extent when compared to non-hermetic system. Thermal exchanges and moisture are less intense than in airtight storage in the non-airtight system. The airtight storage may have led to a reduction in crude protein content depending on the temperature of the storage environment. According to Schuh et al. (2011), high temperatures cause chemical constituents alterations of grains such as lipids, carbohydrates and proteins. The acid value of maize grains decreased with increasing storage time for all treatments, mainly for the batches of mixed maize grains (normal) (Figure 3).

Thus, it can be assumed that storage effects were positive in maintaining the quality of maize, and agree with the results of ashes. There were reductions in the levels of ash over time, regardless of storage and type of corn grain (Figure 4)

The storage with aeration was the type what kept the initial characteristics, such as ash content. At the end of storage, there were greater effects in broken grains, filed smaller percentages of ash. The final ash values were similar for all storage forms.
The metabolic activity of the microorganisms associated grains and consume organic matter metabolizing it to $\mathrm{CO}_{2}$, water and other products, with heat release, and can become structurally mineral composition without altering their total content being accelerated in deterioration cereals with humidity levels above 13-14\%. Thus, the determination of ash content takes proportionately larger values as organic matter is consumed (GIRIO et al., 2012). What can be observed in this study is that water content throughout storage remained low, indicating low deterioration of the grains, and therefore low ash content during storage.

\section{CONCLUSIONS}

The six-month storage time was the main factor contributing to the reduction of the quality of maize grains.

Storage alternatives with aeration, without aeration, in sacks and airtight storage did not influence the physical properties of corn kernels.

The airtight storage and storage bins with aeration retained the physical and chemical quality of maize grain over time.

Broken maize grains showed the worst physical and chemical quality during storage time. The batches of whole corn grains differ in quality during storage.

\section{ACKNOWLEDGEMENTS}

The authors would like to thank the Federal University of Mato Grosso do Sul (UFMS) and the Foundation for Development Support of Education, Science and Technology of the State of Mato Grosso do Sul (FUNDECT - MS) for their financial support for the development of the present research.

RESUMO: O armazenamento de grãos em condições técnicas em ambientais favoráveis garante a sua qualidade dos grãos e regula o fornecimento de matéria-prima para a produção de alimentos. Assim, objetivou-se com este estudo, avaliar as diferentes formas de armazenamento (em silo aerado, em silo sem aeração, em sacaria e hermético) de grãos produzidos no cerrado brasileiro, ao longo do tempo (zero, três e seis meses), para diferentes qualidades físicas de milho (grãos normais, grãos inteiros e grãos quebrados). A pesquisa foi realizada na Universidade Federal de Mato Grosso do Sul (UFMS), Campus de Chapadão do Sul (CPCS), no Laboratório de Pós-Colheita de Grãos. Para determinar a qualidade físico-química e as propriedades físicas dos grãos, ao longo de seis meses, amostras foram coletadas dos lotes de produtos armazenados. O delineamento experimental foi inteiramente casualizado (4x3), quatro formas de armazenamento (hermética, sacaria, sem aeração e com aeração), três tipos de massa de milho (milho normal, milho inteiro, milho quebrado). A análise de variância e as médias pelo teste de Tukey foram comparados a 5\% de probabilidade. O tempo de armazenamento de seis meses foi o principal fator que contribuiu para a redução da qualidade de grãos de milho. Alternativas de armazenamento com aeração, sem aeração, em sacaria e hermético não influenciou nas propriedades físicas dos grãos de milho. Os grãos de milho quebrados apresentaram a pior qualidade física e química durante o tempo de armazenamento. Enquanto que, os lotes de grãos de milho inteiros diferiram na qualidade durante o armazenamento. 
Concluiu-se que, o armazenamento hermético e o armazenamento em silos com aeração foi o que melhor preservou a qualidade física e química dos grãos de milho ao longo do tempo.

PALAVRAS-CHAVE: Teor de água. Qualidade. Região do Cerrado. Temperatura ambiente. Zea mays L.

\section{REFERENCES}

ALENCAR, E. R.; FARONI, L. R. D.; FERREIRA, L. G.; COSTA, A. R. DA; PIMENTEL, M. A. G. Qualidade de milho armazenado e infestado por Sitophilus zeamais e Tribolium castaneum. Engenharia na Agricultura, Viçosa, v. 19, n. 1, p. 9-18, 2011. http://dx.doi.org/10.13083/1414-3984.v19n01a01

ANTONELLO, L. M.; MUNIZ, M. B.; BRAND, S. C.; VIDAL, M. D.; GARCIA, D.; RIBEIRO, L.; SANTOS, V. Qualidade de sementes de milho armazenadas em diferentes embalagens. Ciência Rural, Santa Maria, v. 39, n. 7, p. 2191-2194, 2009. http://dx.doi.org/10.1590/S0103-84782009005000157

ANTUNES, L. E. G.; VIEBRANTZ, P. C.; GOTTARDI, R.; DIONELLO, R. G. Características físicoquímicas de grãos de milho atacados por Sitophilus zeamais durante o armazenamento. Revista Brasileira de Engenharia Agrícola Ambiental, Campina Grande, v. 15, n. 6, p. 615-620, 2011. http://dx.doi.org/10.1590/S1415-43662011000600012

ASSOCIATION OF OFFICIAL ANALYTICAL CHEMISTS. Official methods of analysis of the Association of Official Analytical Chemists. 17. ed. Gaithersburg, Maryland: AOAC, 2000, v. 2. n. 11, p. 4.

BRASIL. Ministério da Agricultura, Pecuária e Abastecimento. Regras para análise de sementes. Brasília: Mapa/ACS, 2009, 399p.

BRASIL. Portaria ${ }^{\circ}$ 611, de 04 de julho de 2012. Alterar os incisos IV e VI do art. 25 e o art. 31, todos da Instrução Normativa ${ }^{\circ}$ 60, de 22 de dezembro de 2011. Diário Oficial [da República Federativa do Brasil, Brasília, DF, n. 129, 5 jul. 2012. Seção 1, p. 10.

CORADI, P. C.; LACERDA FILHO, A. F.; MELO, E. C. Quality of raw materials from different regions of Minas Gerais State utilized in ration industry. Revista Brasileira de Engenharia Agrícola e Ambiental, Campina Grande, v. 15, n. 4, p. 424-431, 2011. http://dx.doi.org/10.1590/S1415-43662011000400015

COSTA, D. M.; MACHADO, L. C. BITTENCOURT, F.; PEREIRA, L. C. Qualidade do milho para nutrição animal comercializado a varejo e métodos para determinação da umidade. Revista Agrogeoambiental, Pouso Alegre, v. 5, n. 2, p. 25-34, 2013.

FAO. Food and Agricultural Organization, Roma, 2012. Food Nutritional.

FERRARI FILHO, E.; ANTUNES, L. E. G.; TIECKER, A.; DIONELLO, R. G.; SPOLTI, P. Controle de gorgulho-do-milho submetido ao tratamento térmico. Revista Brasileira de Milho e Sorgo, Sete Lagoas, v. 10, n. 3, p. 196-204, 2011. http://dx.doi.org/10.18512/1980-6477/rbms.v10n3p196-204

FESSEL, S. A.; PANOBIANCO, M.; SOUZA, C. R.; VIEIRA, R. D. Teste de condutividade elétrica em sementes de soja armazenadas sob diferentes temperaturas. Bragantia, Campinas, v. 69, n. 1, p. 207-214, 2010. http://dx.doi.org/10.1590/S1415-43662014000400013

GIRIO, T. M. S.; NADER FILHO, A.; ROSSI JUNIOR, O. D.; AMARAL, L. A.; GIRIO, R. J. S. Qualidade microbiológica de rações para cães comercializadas no varejo em embalagem fechada e a granel. Ars Veterinaria, Jaboticabal, v. 28, n. 1, p. 36-40, 2012. 
GUBERAC, V.; MARIC, S.; LALIC, A.; DREZNER, G.; ZDUNIC, Z.. Hermetically sealed storage of cereal seeds and its influence on vigor and germination. Journal Agronomy \& Crop Science, Jaboticabal, v. 189, n. 1, p. 54-56, 2003. http://doi:10.1046/j.1439-037X.2003.00596.x

JIAN, F.; LARSON, R.; JAYAS, D. S.; WHITE, N. D. G. Three dimensional temporal and spatial distributions of adult Oryza ephilus surinamensis and Sitophilus oryzae in stored wheat under different temperatures, moisture contents, and adult densities. Journal of Stored Products Research, Manhattan, Kansas, USA, v. 49, n. 3, p. 155-165, 2012. http://doi:10.1016/j.jspr.2012.01.001

MAZZUCO, H.; LORINI, I.; BRUM, P. A. R.; ZANOTTO, D. L.; JUNIOR, W. B.; AVILA, V. S. Composição Química e Energética do Milho com Diversos Níveis de Umidade na Colheita e Diferentes Temperaturas de Secagem para Frangos de Corte. Revista Brasileira de Zootecnia, Viçosa, v. 31, n. 6, p. 2216-2220, 2002. http://dx.doi.org/10.1590/S1516-35982002000900009

MOSHENIN, N. N. Physical properties of plant and animal materials. New York, USA. 1986, 841p.

PANOBIANCO, M.; VIEIRA, R. D. Electrical conductivity and deterioration of soybean seeds exposed to different storage conditions. Revista Brasileira de Sementes, Londrina, v. 29, n. 2, p. 97-105, 2007. http://dx.doi.org/10.1590/S0101-31222007000200013

PUZZI, D. Abastecimento e armazenamento de grãos. Campinas: Instituto Campineiro de Ensino Agrícola, 2000.

SHIROMA, N. N.; DARI, R.; PENZ JUNIOR, A. M. Milho: um importante ingrediente para a avicultura. Revista Nutrition for Tomorrow, v. 4, n. 1, p. 50-55, 2010.

SCHUH, G.; GOTTARDI, R.; FERRARI, E. F.; ANTUNES, L. E. G.; DIONELLO, R. G. Efeitos de dois métodos de secagem sobre a qualidade físico-química de grãos de milho safrinha-RS, armazenados por 6 meses. Semina: Ciências Agrárias, Londrina, v. 32, n. 1, p. 235-244, 2011. http://dx.doi.org/10.5433/16790359.2011v32n1p235

SANTOS, S. B.; MARTINS, M. A.; FARONI, L. R. D. A.; JUNIOR, V. R. D. B. Perda de matéria seca em grãos de milho armazenados em bolsas herméticas. Revista Ciência Agronômica, Fortaleza, v. 43, n. 4, p. 674-682, 2012. http://dx.doi.org/10.1590/S1806-66902012000400008

VIEIRA, R. D.; KRZYZANOWSKI, F. C. Teste de condutividade elétrica. In: VIEIRA, R. D.; KRZYZANOWSKI, F. C.; FRANÇA NETO, J. B. Vigor de sementes: conceitos e testes. Londrina, PR: ABRATES, 1999, cap. 4, p. 1-26. 